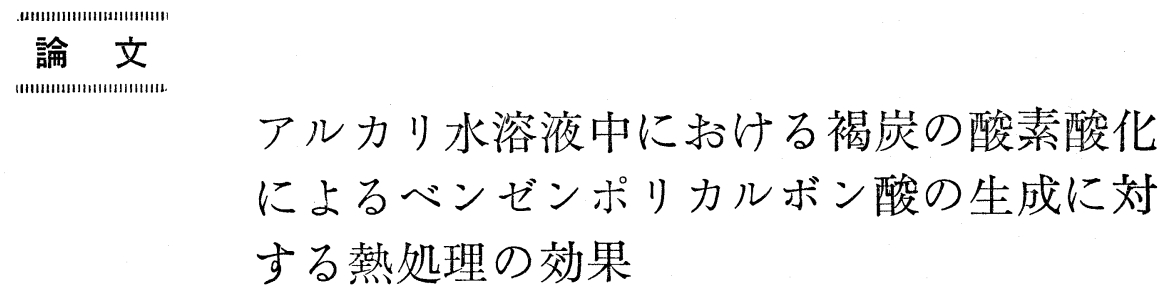

-1986. 4. 2 受理一

東京大学 神谷 佳男, 熊谷 善 敏

\section{1. 緒言}

石炭の酸化分解 ${ }^{1) 21}$ は, 酸化生成物の構造決定による 石炭化学構造の推定と, 生成酸の有效利用を目的とし て古くから多くの研究者により実施されてきた。使用 された酸化剂 ${ }^{1)}$ は多岐に亘るが，酸素と硝酸がおもな ものである。アルカリ水溶液中に执ける酸化2)314)の実 施例が多いが, この方式の酸化の特徵は, 初期酸化生 成物であるフミン酸（分子量～1000前後）が速やかに 溶解し, 律速段階である水溶性低分子量酸への酸化分 解反応が均一相で円滑に進行することである。水可溶 芳香族ポリカルボン 酸の収率は, MEK 抽出物として 60〜 70\%に達するが，原料石炭としては炭素含量 $85 \%$ 以上の歴青炭または低石炭化度炭を熱処理したものが 適当であると報告 ${ }^{576)}$ されている。アルカリ水溶液中で 酸素酸化する方式は, 石炭からベンゼンポリカルボン 酸を製造するプロセスとして有望であり, Howard ら 3)执よび筆者45)7)により詳細に検討されているが，最 近，奥脇ら ${ }^{8)}$ によりシュウ酸を製造する観点から検討 されている。

水可溶芳香族酸の主成分はベンゼンポリカルボン酸 であるが，とくにトリー特よびテトラーカルボン酸が多 く，合成樹脂などの原料として有望視されている。

アルカリの種類, 濃度などの効果については, 筆者
の詳細な研究4)517)がある。アルカリとしては, 苛性ア ルカリでも炭酸アルカリでも生成芳香族酸の収率には あまり差がない。プロセスとしては，20\%程度の $\mathrm{Na}_{2}$ $\mathrm{CO}_{3}$ 水溶液を使用し, 空気を酸化剂とし, 生成炭酸ガ スを連続的に除去しながら反応を行い, $\mathrm{Na}_{2} \mathrm{CO}_{3}$ は冷却 晶析して循環使用する力式 ${ }^{519)}$ がベストであろら。装 置の型式にもよるが，270 ${ }^{\circ} \mathrm{C}, 60 \sim 120$ 分，酸素分珐 10 $\mathrm{kg} / \mathrm{cm}^{2}$ 程度の条件が最適であることが確かめられてい る。

本論文では，最近廉価な資源として注目されている オーストラリア・ビクトリア州褐炭からアルカリ／酸 素酸化法により好収率でベンゼンポリカルボン酸を製 造することを目的として，褐炭の熱処理拉よび抽出液 化処理が生成酸の収率和よび組成に与学に影響を明ら かにするために行った実験結果について述べる。

\section{2. 実験方法および生成物の分析}

\section{1 試料褐炭および熱処理方法}

試料ヤルーン褐炭の元素分析值をTable 1 亿示す。 熱処理方法は乾燥褐炭 $30 \mathrm{~g}$ を $300 \mathrm{~m} \ell$ 電磁擤挥式オート クレーブに入れ，窒素置換したのち所定温度で 1 時間 加熱した。 $\mathrm{CO}_{2}, \mathrm{CO}, \mathrm{CH}_{4}, \mathrm{C}_{2} \mathrm{H}_{6}$ など生成ガスはガスク ロにより分析し，全ガス量から生成量を求めた。固体 成分は乾燥後酸化試料とした。

Table 1 Elemental analysis of original and thermally treated Yallourn coal

\begin{tabular}{ccccc}
\hline & Original coal ${ }^{\mathrm{a}}$ & $\mathrm{A}\left(300^{\circ} \mathrm{C}\right)$ & $\mathrm{B}\left(400^{\circ} \mathrm{C}\right)$ & $\mathrm{C}\left(500^{\circ} \mathrm{C}\right)$ \\
\hline $\mathrm{C}$ (wt $\%$, daf) & 65.8 & 74.5 & 84.0 & 89.8 \\
$\mathrm{H}$ (wt $\%$, daf) & 5.1 & 4.4 & 3.8 & 3.1 \\
$\mathrm{~N}$ (wt $\%$, daf) & 0.5 & & & \\
$\mathrm{~S}$ (wt $\%$, daf) & 0.2 & & & \\
\hline
\end{tabular}

a) Ash content $2.5 \mathrm{wt} \%$ dry coal basis

工学部反応化学科 東京都文京区本郷 7 


\section{2 石炭の抽出液化処理}

乾燥褐炭 $20 \mathrm{~g}$ ，テトラリンまたは1ーメチルナフタレ ン/テトラリン混合液(1/1) $60 \mathrm{ml} 300 \mathrm{ml}$ 電磁攪找式 オートクレーブに入れ, 水素初圧 $20 \mathrm{~kg} / \mathrm{cm}^{2}$ に掠いて400 ${ }^{\circ} \mathrm{C}, 30$ 分抽出液化反応を行った。反応後固体成分を THF で 24 時間ソックスレー抽出し, 不溶分を減圧下 $110^{\circ} \mathrm{C}$ で乾燥し試料とした。残渣の収率は, それぞれ 16.0 特よび22.5\%であった。

\section{3 石炭の酸化反応}

試料炭 $2.5 \mathrm{~g}, 2.5 \mathrm{~N} \mathrm{NaOH}$ 水溶液 $80 \mathrm{ml}$ 女内容積 200 $\mathrm{m} \ell$ 電磁靦挥式オートクレーブに入れ，酸素初圧 $30 \mathrm{~kg} /$ $\mathrm{cm}^{2}$ とし, 約 60 分で $270^{\circ} \mathrm{C}$ に昇温し, 所定時間酸化を行 った。

\section{4 酸化生成物の分析}

酸化生成物の分離は前報 ${ }^{10)}$ にならって行ったが，そ の概要と分析方法を以下に述べる。

反応終了液はろ過して灰分を除き，ろ液を硫酸酸性 として析出する少量の水不溶酸をろ別した。ろ液はべ ンゼン, エーテル, MEKで順次抽出し, 各成分はジ アゾメタンによりメチルエステル化し, 生成エステル をガスクロ（島津 $\mathrm{GC}-4 \mathrm{CPF}$ ，カラム：シリコンOV17, $3 \mathrm{~mm} \phi \times 4 \mathrm{~m}$ キャリアガス: $\mathrm{N}_{2} 40 \mathrm{~m} \ell / \mathrm{min}$ )で分析 し，標品と比較して定量した。

ベンゼン抽出物中には, 安息香酸, 2-ナフトエ酸, セバシン酸などの存在が認められたが，いずれも少量 であった。エーテル抽出物には, ベンゼンジーおよび トリーカルボン酸が主成分として含まれていたが，少 量のベンゼンテトラカルボン酸と脂肪族ジカルボン酸 も含まれていた。MEK抽出物の主成分は,ベンゼント リー,テトラーおよびペンターカルボン酸であった。抽出

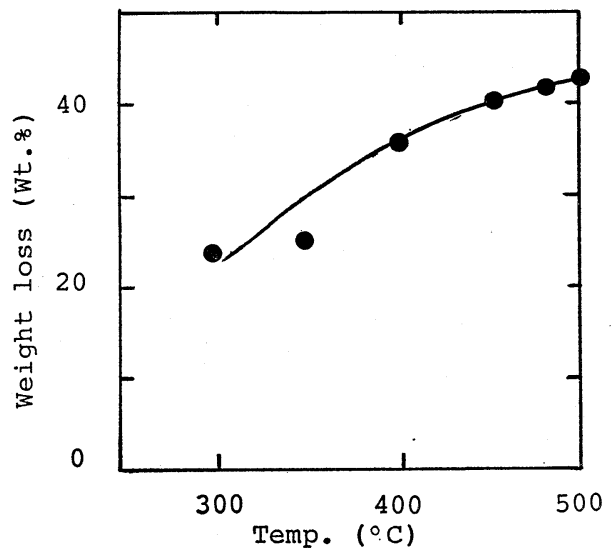

Fig. 1 Weight loss of Yallourn coal by thermal treatment
を完全に行らために, MEK 抽出は水層と同量で 5 回 行ったがベンゼンペンターおよびヘキサーカルボン酸の 分離は不充分であった。したがって、ペンター拉よびへ キサーカルボン酸については, 高速液ク口（島津 LC-3 A, カラム : Shodex Ionpak C-88, $8 \mathrm{~mm} \phi \times 500 \mathrm{~mm}$, 移動層: $0.1 \%$ リ酸水溶液, $2.0 \mathrm{~m} \ell / \mathrm{min}$, 検出器 : 紫 外 $254 \mathrm{~nm}$ ) により定量を行った。今回はベンゼンカル ボン酸以外の成分の分析は行わなかった。

\section{3. 実験結果および考察}

3.1 熱処理によるヤルーン褐炭の性状変化 ヤルーン褐炭の熱分解は $300^{\circ} \mathrm{C}$ 付近から著しくなり 固体成分の重量減少はFig.1に示すように, $300^{\circ} \mathrm{C}$ に括 いて $20 \% ， 450^{\circ} \mathrm{C}$ に和いて $40 \%$ に達する。生成ガスの 分析結果 (Fig.2) によると, $300^{\circ} \mathrm{C}$ に和ける生成ガス は炭酸ガスが圧倒的に多く, 少量の一酸化炭素を副生 するだけであるが，500 Cに拈いては相当量のメタン が炭酸ガスと同時に生成した。

熱処理による褐炭の減少量から $\mathrm{CO}_{2}, \mathrm{CO}, \mathrm{CH}_{4}$ の重 量を差引いた值は， $400{ }^{\circ} \mathrm{C}$ 前後に执いて約 $10 \%$ であっ たが，その大部分は生成水であると推定される。

熱処理炭の元素組成 (Table 1) から計算すると, 褐

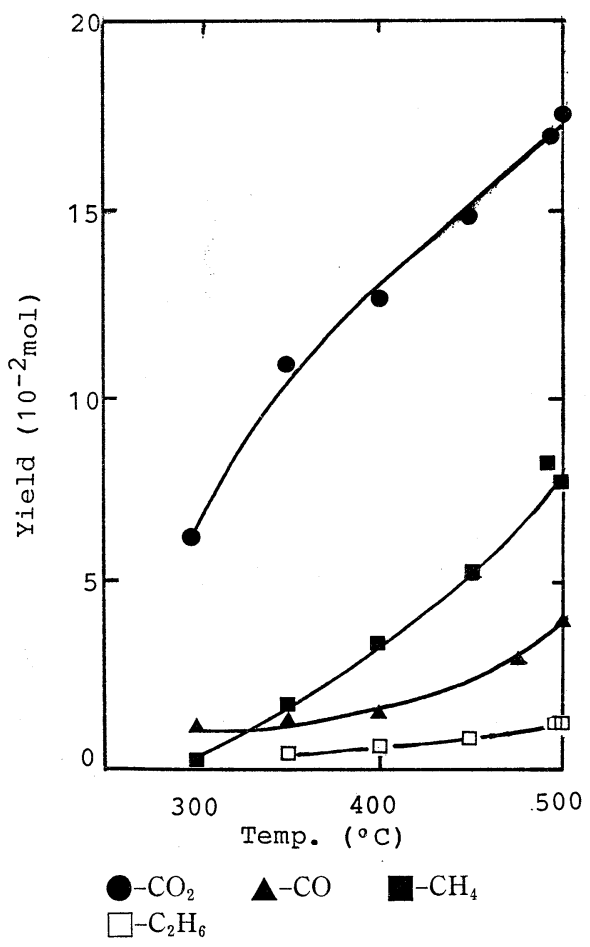

Fig. 2 Yield of gaseous products by thermal treatment

Reaction conditions : Nitrogen atmosphere $\left(1 \mathrm{~kg} / \mathrm{cm}^{2}\right)$, Coal $30 \mathrm{~g}$, Time $60 \mathrm{~min}$ 
Table 2 Effect of reaction time on the yield of benzenepolycarboxylic acids from the oxidation of Yallourn coal

\begin{tabular}{|c|c|c|c|c|}
\hline \multirow{2}{*}{ Benzenecarboxylic acids } & \multicolumn{4}{|c|}{ Acids yield (wt $\%$, daf coal) at reaction time } \\
\hline & $60 \mathrm{~min}$ & $120 \mathrm{~min}$ & $180 \mathrm{~min}$ & $240 \mathrm{~min}$ \\
\hline Benzenedicarboxylic ${ }^{\text {a) }}$ & 0.18 & 0.19 & 0.19 & 0.21 \\
\hline$(1,2)$ & $(0.13)$ & $(0.14)$ & $(0.13)$ & $(0.13)$ \\
\hline$(1,3)$ & $(0.05)$ & $(0.05)$ & $(0.06)$ & $(0.08)$ \\
\hline Benzenetricarboxylic & 1.48 & 1.81 & 1.56 & 1.60 \\
\hline$(1,2,4)$ & $(0.90)$ & $(1.00)$ & $(0.95)$ & $(0.91)$ \\
\hline$(1,2,3)$ & $(0.51)$ & $(0.68)$ & $(0.49)$ & $(0.52)$ \\
\hline$(1,3,5)$ & $(0.07)$ & $(0.15)$ & $(0.12)$ & $(0.16)$ \\
\hline Benzenetetracarboxylic & 4.31 & 4.27 & 3.85 & 3.52 \\
\hline$(1,2,4,5)$ & $(1.21)$ & $(1.17)$ & $(1.10)$ & $(1.00)$ \\
\hline$(1,2,3,4)$ & $(1.57)$ & $(1.51)$ & $(1.31)$ & $(1.04)$ \\
\hline$(1,2,3,5)$ & $(1.54)$ & $(1.59)$ & $(1.44)$ & $(1.48)$ \\
\hline
\end{tabular}

Oxidation conditions : Coal $2.5 \mathrm{~g}$, Initial $\mathrm{O}_{2}$ pressure $30 \mathrm{~kg} / \mathrm{cm}^{2}, 2.5 \mathrm{~N} \mathrm{NaOH} 80 \mathrm{~m} \ell, 270^{\circ} \mathrm{C}$

a) Yield of benzenedicarboxylic $(1,4)$ acid was negligible

炭に含まれる酸素の80～90\%が400～500 ${ }^{\circ} \mathrm{C}$ 熱処理に より脱離したことを示している。

3.2 熱処理によるベンゼンポリカルボン酸の収率 増加について

褐炭の酸化反応の進行に伴うベンゼンジー,トリー拉 よびテトラーカルボン酸の生成量の変化をTable 2に示 す。時間の経過につれてテトラカルボン酸はかなり減 少し, ジー执よびトリーカルボン酸は若干増加した。こ れは脱カルボキシル基および生成酸の酸化分解に起因 すると考えられるが, 各種モデル化合物の酸化分解実 験 ${ }^{11)}$ による, $270^{\circ} \mathrm{C}, 120$ 分程度の酸化条件では, 側 鎖メチル基, ナフタレン環, ヒドロキシル置換基を有 するベンゼン環はほとんど酸化分解されることが確か められている。また, 生成カルボン酸のメチルエステ ルを減圧蒸留して得られる留出分 ${ }^{12)}$ は, ほとんどベン ゼンポリカルボン酸のエステルのみより成ることが明 らかにされているが，本実験により得られた試料のガ スクロマトグラムも， ベンゼンカルボン酸留分はほと んど不純物を含まないことを示していた。

以上の結果, アルカリ-酸素酸化の標準条件として は，芳香族構造の発達した熱処理炭の酸化分解を完全 に進行させるために， $270^{\circ} \mathrm{C} ， 180$ 分を適用することに した。

ベンゼンポリカルボン酸の収率に対する熱処理温度 の効果をFig.3に示す。加熱処理の効果は顕著であり, 合計収率は $450 \sim 500^{\circ} \mathrm{C}$ 処理炭で $36 \%$ に達する。この収 率は, 加熱処理による褐炭重量の減少を考慮した未処 理炭基準でも約 $20 \%$ に達し，熱処理の結果，芳香族構
造の発達あるいは脱ヒドロキシル基反応などにより褐 炭がベンゼンポリカルボン酸を生成し易い化学構造に 変化したものと考えることができる。

生成したベンゼンポリカルボン酸の最多成分はテト ラカルボン酸であるが (約 $12 \%), 450^{\circ} \mathrm{C}$ 熱処理炭につ いては，トリーおよびペンターカルボン酸も各 $7 \%$ 程度 生成し, ジー拉よびヘキサーカルボン酸も各 $4 \%$ の值を 示した。

各成分の組成に括ける特徴は, 熱処理の結果, ベン ゼントリカルボン酸については, $(1,2,3)$ カルボン酸 が増加すること,テトラカルボン酸については $(1,2,3$, 4) カルボン酸が増加すること，拉よびへキサカルボ ン酸の収率がかなり高くなることである。

前報 ${ }^{12)}$ に抢いて示したように，石炭酸化により生成 するベンゼントリカルボン酸の主成分は $(1,2,4)$ カル ボン酸であるが，加熱処理炭については $(1,2,3)$ カル ボン酸が最多成分に変化する現象は，本研究に打いて も認められて扤り (Table 3), 熱処理によりカルボキ シル基が隣接した成分が増加することは興味深い事実 である。

また，酸化によるベンゼンヘキサカルボン酸（メリ ット酸)の収量が, 試料の石炭化度に比例して増加し, 無煙炭やコークスの場合にもっとも高くなることは, 過マンガン酸カリウム酸化において認められている著 名な事実 ${ }^{13)}$ である。

ベンゼンポリカルボン酸の合計収率36\%は，高石炭 化度歴青炭および熱処理太平洋炭についての収率 ${ }^{2)} 25$ 〜30\%に比してかなり高いが，これはヤルーン炭の熱 


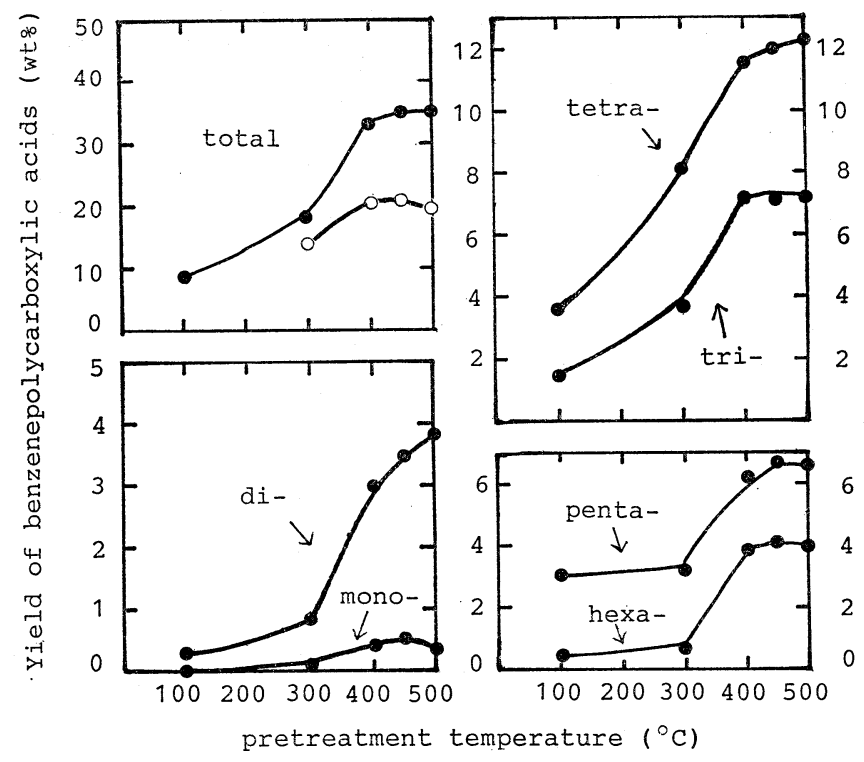

- Yield on the basis of treated coal

$\bigcirc$ Yield on the basis of untreated coal

Oxidation conditions : Coal $2.5 \mathrm{~g}$, Initial $\mathrm{O}_{2}$ pressure $30 \mathrm{~kg} / \mathrm{cm}^{2}, 2.5 \mathrm{~N} \mathrm{NaOH} 80 \mathrm{ml}, 270^{\circ} \mathrm{C}, 3 \mathrm{hrs}$

Fig. 3 Effect of thermal pretreatment on the yield of benzenepolycarboxylic acids

Table 3 Effect of thermal treatment on the yield of benzenecarboxylic acids from Yallourn coal

\begin{tabular}{ccc}
\hline \multirow{2}{*}{ Benzenecarboxylic acids } & \multicolumn{2}{c}{ Yield of acids (wt $\%$ ) } \\
& Original coal & Treated coal at $500^{\circ} \mathrm{C}$ for $1 \mathrm{hr}$ \\
\hline Benzoic & 0.05 & 0.44 \\
Benzenedicarboxylic & 0.19 & 3.9 \\
$(1,2)$ & $(0.13)$ & $(3.4)$ \\
$(1,3)$ & $(0.06)$ & $(0.5)$ \\
Benzenetricarboxylic & 1.6 & 7.7 \\
$(1,2,3)$ & $(0.15)$ & $(3.8)$ \\
$(1,2,4)$ & $(1.0)$ & $(3.6)$ \\
$(1,3,5)$ & $(0.1)$ & 12.5 \\
Benzenetetracarboxylic & 3.8 & $(6.3)$ \\
$(1,2,3,4)$ & $(1.3)$ & $(2.4)$ \\
$(1,2,3,5)$ & $(1.1)$ & 7.2 \\
$(1,2,4,5)$ & $(1.4)$ & 4.2 \\
Benzenepentacarboxylic & 2.9 & 35.9 \\
Benzenehexacarboxylic & 0.4 & \\
Total acids & 8.9 & \\
\hline
\end{tabular}

Oxidation conditions : see Fig. 3 
処理物が適当な原料之考兄られるほかに, 生成物の分 離, 分析方法の相違があげられよう。前報67飞打いて は, MEKによる 2 回抽出を行ったために, ベンゼン ペンター拈よびヘキサーカルボン酸の回収が不充分であ ったと推定され，また，カルボン酸の収率をメチルエ ステルの減圧蒸留による実際の得率から求めた前報の 方式では, 今回行ったメチルエステルのガスクロ分析 方式よりやや低い值を示すことは止むを得ないことで あるう。

\section{3 石炭液化反応残渣の酸化}

石炭液化反応飞怙ける不溶性成分 ${ }^{14)}$ は，炭素含量が 高く芳香族構造が発達した組成を有することが認めら れている。いわゆる液化残渣は, 燃料あるいはガス化 原料として利用する方式が提案されているが，芳香族 性に富む特徴を活用して，酸化原料として使用する方 式も考光られる。

ヤルーン炭を $400^{\circ} \mathrm{C}$ に括いて，テトラリンをたは 1 メチルナフタレン/テトラリン混合液で処理して得ら れた THF 不溶分についてアルカリ/酸素酸化を行い, 生成ベンゼンカルボン酸を分析した結果を Table 4 に
示す。

ベンゼンカルボン酸の合計収率は，それぞれ $20.5 \%$ ， $23.2 \%$ でり，いずれも未処理炭の $2.3 \sim 2.7$ 倍の值を 示した。THF 不溶分が縮合芳香族環飞富むことを証 明する事実として興味深い。

生成酸の成分としては, テトラカルボン酸が最も多 く,トリー特よびペンターカルボン酸がこれに次ぐ点で 熱処理炭の結果と類似している。また， $(1,2,3)$ およ び $(1,2,3,4)$ カルボン酸成分に富点点も熱処理炭と同 様な結果であるということができる。

石炭液化反応の初期過程は, 本質的飞熱分解反応で あるが，液化反応の場合には還元的雾囲気であるため に, 生成ラジカルに対する水素供与によって分解生成 物の縮合が抑制され，縮合芳香族環構造の発達がかな り阻害されるために， $400^{\circ} \mathrm{C}$ 熱処理炭よりもかなり酸 收率が低い結果が得られたものと推測される。

しかし, 液化残渣を酸化分解すると, かなりの収率 でベンゼンポリカルボン酸を生成する上述の結果は, 酸化分解が液化残渣の有力な処理法のひとつとして考 慮できることを示唆している。

Table 4 Yield of benzenecarboxylic acids by the oxidation of THF-insolubles after the liquefaction of Yallourn coal ${ }^{\text {a }}$

\begin{tabular}{ccc}
\hline \multirow{2}{*}{ Benzenecarboxylic acids } & Yield of acids (wt $\%$, daf coal) \\
& $\mathrm{A}^{\mathrm{b})}$ & $\mathrm{B}^{\mathrm{c})}$ \\
\hline Benzoic & 0.13 & 0.09 \\
Benzenedicarboxylic & 2.06 & 2.08 \\
$(1,2)$ & $(1.83)$ & $(1.89)$ \\
$(1,3)$ & $(0.23)$ & $(0.19)$ \\
Benzenetricarboxylic & 4.34 & 4.62 \\
$(1,2,3)$ & $(2.16)$ & $(2.30)$ \\
$(1,2,4)$ & $(2.05)$ & $(2.18)$ \\
$(1,2,5)$ & $(0.13)$ & $(0.14)$ \\
Benzenetetracarboxylic & 7.04 & 8.00 \\
$(1,2,3,4)$ & $(2.19)$ & $(3.38)$ \\
$(1,2,3,5)$ & $(2.38)$ & $(2.48)$ \\
$(1,2,4,5)$ & $(2.47)$ & $(2.14)$ \\
Benzenepentacarboxylic & 3.85 & 4.87 \\
Benzenehexacarboxylic & 3.11 & 3.55 \\
\hline Total acids & 20.5 & 23.2 \\
\hline
\end{tabular}

a) Coal liquefaction conditions : $400^{\circ} \mathrm{C}$, Initial $\mathrm{H}_{2}$ pressure $20 \mathrm{~kg} / \mathrm{cm}^{2}, 30 \mathrm{~min}$, Coal $20 \mathrm{~g}$

b) THF-insolubles after treating by $30 \mathrm{~m} \ell$ tetralin and $30 \mathrm{~m} \ell$ 1-methylnaphthalene at $400^{\circ} \mathrm{C}$

c) $\mathrm{THF}$-insolubles after treating by $60 \mathrm{~m} \ell$ tetralin at $400^{\circ} \mathrm{C}$

d) Oxidation conditions : see Fig. 3 
本研究では，実験の簡便さから $\mathrm{NaOHをアルカリと}$ 乙て使用したが，上述したようと， $\mathrm{Na}_{2} \mathrm{CO}_{3}$ を使用して も，炭酸ガスを連続的に除去する装置7を用いれば， 生成芳香族カルボン酸の収率は同様であることが, 既 報の実験(5)により確かめられている。

\section{4. まとめ}

豪州褐炭をアルカリ水溶液中で酸素酸化し, ベンゼ ンポリカルボン酸を收率よく製造することを目的と 乙，300 $500^{\circ} \mathrm{C}$ 飞招いて 熱処理の効果を検討した結 果，次のような知見を得た。

1）ヤルーン炭を $450 \sim 500^{\circ} \mathrm{C}$ で熱処理すると, 酸化 によるベンゼンポリカルボン酸の収率は約 $36 \%$ に增加 する。生成酸の最多成分はテトラカルボン酸であり, トリー怙よびペンターカルボン酸がこれに次ぐ量であっ た。熱処理炭からの生成酸は $(1,2,3,4)$ およ゙ $(1,2,3)$ カルボン酸を多量に含む特徵がある。

2）石炭の液化残渣は, 未処理炭に比して約 2.5 倍 のベンゼンポリカルボン酸を生成する。酸の成分組成 は熱処理炭と同様な傾向を示した。

\section{文献}

1) Hayatsu, R., Scott, R.G. and Winans, R.E., "Oxidation in Organic Chemistry, Part D,

Chap. 4" Academic Press (1982)
2）神谷佳男，燃協誌， $58 ， 148$ (1979)

3) Franke, N.W., Kiebler, M.W., Ruof, C.H., Savich, T.R. and Howard, H.C., Ind. Eng. Chem., 44, 2784 (1952)

Ruof, C.H., Savich, T.R. and Howard, H.C., J. Amer. Chem. Soc., 73, 3873 (1951)

4) Kamiya, Y., Fuel, 40, 149 (1961)

5）安東新午, 神谷佳男, 燃協誌, 40, 88 (1961)

6) 神谷佳男, 工化誌, 65, 382 (1962)

7）神谷佳男, 工化誌, 62, 106 (1959)

8）須藤信行, 老久保弘美, 奥脇昭䃋, 天野 某, 岡部泰二郎, 日化, 1418 (1984) ほか

9）神谷佳男, 化学工業, 6, (10), 65 (1962)

10）神谷佳男, 工化誌, 59, 197 (1956)

11) Kamiya, Y., Fuel, 42, 353 (1963)

12）神谷佳男, 工化誌, 61, 1169 (1958)

13) van Krevelen, W., "Coal”, p.221, Elsevier (1961)

14）佐藤寛樹，神谷佳男，燃協誌，56，103（1977）

\title{
Effect of Thermal Pretreatment on the Yield of Benzenepolycarboxylic Acids from the Oxygen- oxidation of Australian Brown Coal in Alkaline Medium
}

\author{
Yoshio KamiYa and Yoshihiro KUMAGAI \\ (Faculty of Engineering, University of Tokyo)
}

\begin{abstract}
SYNOPSIS : - In order to obtain benzenepolycarboxylic acids in good yield by the oxygen oxidation of Australian brown coal in alkaline aqueous solution, the effect of thermal pretreatment at temperatures from 300 to $500^{\circ} \mathrm{C}$ was studied. It was found that the pretreated brown coal at temperatures from 450 to $500^{\circ} \mathrm{C}$ has shown a higher yield of benzene polycarboxylic acids (total $36 \%$, tetracarboxylic $12.5 \%$, tricarboxylic $7.7 \%$, pentacarboxylic $7.2 \%$ ) as compared with the previous results on a high rank bituminous coal and a precarbonized subbituminous coal. The THF insoluble fraction from the liquefaction of brown coal in hydrogen donor solvent at $400^{\circ} \mathrm{C}$ yielded higher amount of benzenepolycarboxylic acids than the original brown coal.
\end{abstract}

\section{Key Words}

Oxidation of coal, Benzenecarboxylic acids,

Carbonization of brown coal 